\title{
Moving a Seminary Library 400+ Miles
}

By Bob Phillips, Gateway Seminary of the Southern Baptist Convention, Patsy Yang, Gateway Seminary of the Southern Baptist Convention

\begin{abstract}
This poster session summarizes the librarians' role in Gateway Seminary's relocation of its main campus from Northern California to Ontario, California, four hundred miles south. The move affected both staff and the library collections. The poster is available here. The Proceedings submission includes lessons we learned from the move that will be helpful for any library planning to move to a new or renovated space.
\end{abstract}

Poster available at https://schd.ws/hosted_files/atla2018/78/Movinga-Library-400-Miles.pdf

This poster session summarizes the librarians' role in Gateway Seminary's relocation from Northern California to Ontario, California, 400 miles south. This was not the library's first move. Two of us had participated in other moves earlier in our careers-much like the Golden Gate library move in 1981. The original campus library was moved from a smaller space on the upper floor of the administration building to its new building a few yards away. That move was done by students and staff, one book truck at a time. Those who were a part of the move remember it as a lot of walking, but not much else. The advance planning focused on design, construction, and furnishing.

The 2016 move was different. The poster describes what was done. What did we learn that might help those facing their own possible campus move, should the school decide to keep its library mostly intact?

1. Take time to plan. Fortunately, we had two years to wait before the new building was ready for occupancy.

2. If you have not moved a library before, it is not too different from moving a household. Decide what to take and dispose of what is left. Set a timeline using approximate dates and adjust as you go. 
3. Find an experienced library mover. Separate the furniture move from the materials move. Anyone can move furnishings, yet not everyone can keep tens of thousands of books in shelf order and remove and re-install library shelving.

4. Moving the shelving increases complexity. New installation needs to meet local building codes.

5. Know how many linear feet of material you will move. It is not as difficult to determine this as it seems. We used a 25 -foot length of string to measure the empty space on each shelf.

6. Dispose of "low hanging fruit" first. The seminary had closed its NASM accredited church music programs over ten years earlier. The books, journals, and sheet music were still on the shelves. We also disposed of journal back-runs for which we had full-text online.

7. Recognize that it takes effort to dispose of unwanted material. This may become more difficult as more printed material morphs into electronic format. We were fortunate that New Orleans Baptist Seminary took our music scores, Northeast Baptist College took our music books, and several Christian colleges were able to use our bound periodicals. Despite our generosity, we still sent thousands of books to the Marin County landfill because we could not find a recycler for hardbound items.

8. When you relocate a campus, you are also relocating faculty and staff. Some may choose not to move to the new location. Two librarians found other employment before the move. Two retired once the move from Mill Valley was completed. New staff were hired and trained during and immediately after the move.

9. Once the movers complete their tasks, you are on your own. The whole campus moved into the building the same week. Everyone was busy. It was a great time to build community with everyone else in the building as all worked together to help each other to prepare the building for opening day. Once the furniture was reassembled and placed and the boxes of supplies and other material were distributed, the library staff was on its own. It took another six months to shelve and re-organize our special collections and archives room, and it took two years before we organized our storeroom. 
10. Expect everything to take longer than you think it will and be ready for the unexpected. When we moved into the Ontario building, we learned that there would be no intranet, internet, or phone access for several weeks, and some important equipment took several months to be available for use. Because the IT staff had larger issues to resolve, the library's KWIC scanner was not available for several months.

11. Remember that you are part of a faith-based organization. Keep the institutional mission in mind. What you are doing will have a lasting effect. 